\title{
The influence of developing technology and mother's songs; lullabies ${ }^{1}$
}

\author{
Saibe Özlem Kaya ${ }^{2}$ \\ Berna Özkut ${ }^{3}$
}

\begin{abstract}
Just like changing every phenomenon of life, developing technologies have affected mother's songs/lullabies, which are precious treasures of our culture and they are technologically shaping our mother's songs/lullabies in an artificial way. Today, with the developing technology we are able to make the babies listen to lullabies without touching the babies or without having eye contact with the babies. In fact, this situation affects mother-infant communication and interaction and the quality bond between mother-infant adversely. Compared to the impact of mother's singing the lullabies traditionally to the baby by touching, looking and stroking; the impact of making the babies listen to the lullabies with technological tools has become a matter of discussion. However; the latter is not as effective as the lullabies that are sung with the mother's natural voice and are important treasure chest of our own culture. Thus, it was aimed with this study to investigate the effect of today's technology on mother's songs/lullabies that are very significant artistic aspect of the communication between mother-infant and hold a very deep place in our culture.
\end{abstract}

Keywords: Technology, Music, Mother /Song, Lullaby

\section{INTRODUCTION}

Once the scientific studies relevant with lullabies are reviewed, it can be understood that the first written and identified lullaby texts go back to the Sumerians (Çı̆ 2002: 213). The lullabies have arisen during the communication between the mother and the baby since ancient times. The lullabies which we are accustomed to hearing from the mothers' natural tone and without instruments have begun to come up in different forms over time. Technological developments in all areas, cultural change processes and their reflections in the music industry have helped the emergence of new forms. Most of the mothers do not consider the lullabies as important and not give enough attention to them because of some reasons such as rapid changes and developments in work and daily life, particularly in recent years, increase in their duties and responsibilities, prolongation of the working times. Some mothers cannot allocate time to the baby because of work intensity and when the mother comes home from work, the baby is already in sleep. Some mothers do not have sufficient knowledge and qualified complements both on the lullabies (words, etc.) and

\footnotetext{
1 This article was presented at the 1st International Conference on Lifelong Education and Leadership, in Olomouc, Czech on October 29-31, 2015.

2 Lecturer, Department of Preschool Teaching, Division of Elementary Teaching Faculty of Education, Afyon Kocatepe University, saibezlem@yahoo.com

${ }^{3}$ Lecturer, Sy., Department of Performing Arts, State Conservatory, Afyon Kocatepe University, brnkut@hotmail.com
} 
Kaya, S. Ö., \& Özkut, B. (2016). The influence of developing technology and mother's songs; lullabies. International Journal of Human Sciences, 13(1), 778-786. doi:10.14687/ijhs.v13i1.3586

how to sing (tunes, etc.). Some of the mothers started formatting a digital and artificial tradition by allowing their babies listen to the lullaby albums prepared for babies by the performers in the music

industry or toys singing lullabies instead of singing the mother-created lullaby to the baby with their natural voice. In some families, the babies are allowed to listen to various music pieces of the popular culture through the tools such as the internet, radios, TV and cell phones. These are not as effective and magical as mother's natural tone, timbre and mother's performance of lullaby singing. Mothers not only use these digital and artificial technologies when to put the baby to sleep but also when dressing baby, breastfeeding the baby, calming down the baby's differentiated cries. Therefore, it is possible to say that the technology has taken on new forms and functions in the communication with the baby. In the oral culture media, the television programs and the internet have taken the place of mothers, who were supposed to be active in the execution of lullaby singing. This state reduced the magic powers of the mothers and lessened their creativity and virtually made the mothers ineffective. Finally this situation deprived the babies of the essential maternal songs performed with the mother's body and verbal language.

In today's technology, the internet is another means of communication that affects the mother's singing a lullaby as mentioned above. The websites for both mother and children offer especially to mother traditional lullabies as well as lullabies written by some specific persons. The lullabies and songs learned from the internet sites are used to put the baby to sleep. Moreover, the lullabies that are learned from the internet and have become very common today lead the mothers to become more passive in creativity and in singing the lullabies. The lullaby CDs, which facilitate the sleep of babies, change the traditional lullaby singing culture and make it totally artificial by dropping the eye contact with the baby, cutting out the habit of patting the baby, rocking the baby on feet, arms and in the crib in the execution of lullaby singing. So, all these media tools cause the live performances to take place in a just one-way form. Therefore, the case in which the women reflect their inner world by the lullabies also has become void. That is to say, it is not the mother that performs the lullaby. The link established between mother and baby is created with the artificial media tools. Unfortunately; and today's modern technological tools have made the tradition of lullaby singing artificial and replaced the mothers. In such an environment there is no communication based on words so mothers cannot communicate the emotional intensity in their own language. This case makes both mother and the baby to go through an introvert personality. However, when lullabies are called, we picture a figure of mothers, babies and cradles in our minds, our souls and our imagination.

Mothers have started living in the electronic culture medium and become introverted individuals in this society. Thus, these developments made it difficult for them to live up the folk culture products along with undermining their role of keeping folk culture alive (Tezcan, 2000: 235). Therefore, the mothers drift apart from singing the traditional lullabies. Recording and storing the lyrics, tunes and music and packaging the song words and music (called as mediated performances) (Çobanoğlu 2000: 153) in the electronic culture media mean that it is partially the termination of communication and interaction by the parties during the performance of the lullabies. Putting the babies to sleep through the cassettes or CDs that are used to lull the baby partially eliminates the communication function of children's lullaby. Because the communication that is provided by the sound, skin and eye contact between mother and baby during the execution of a lullaby disappears once a machine intervenes between them. This is because, "Communication is a phenomenon among subjects and is duplex. However, it is not the case for media and digital models "(Ong 1995: 207).

It should be noted that because of the situations above mentioned, mothers who are important lullaby performers should not be reduced to the status of "charity beggars sitting on the treasure chest" (Demir: 2008). 
Kaya, S. Ö., \& Özkut, B. (2016). The influence of developing technology and mother's songs; lullabies. International Journal of Human Sciences, 13(1), 778-786. doi:10.14687/ijhs.v13i1.3586

Many studies indicate that during the execution of the lullaby singing, an eye contact with the baby should be made, the baby should be stroked and the baby could be swung. This is because it makes the babies react positively to the lullaby. In fact, many babies sleep without providing all these conditions.

Each time starts singing lullabies to the baby; the mother sends a group of cultural and social messages, which are totally accepted in society. With these messages, mother transfers the social and cultural codes to the baby and enables the continuity and the reproduction of cultural codes. Thus, values education by the mother to the baby through the lullaby with mother's voice, touch, eye contact and movement of shaking and swinging is transferred to the baby through musical thesis.

The position taken by the mother when singing the lullaby and moving her body according to the rhythm of the cradle become the facilitating instruments of the verbal expression and helps the mother find peace in this environment. The mother may calm down and relax with the quiet environment that is set for the baby and her spirit and body may be renewed. Thus, thanks to the verbal communication's feature of joining the people (Ong 1995: 87), perhaps the most important and magical bond between mother and baby will be founded by the lullaby songs themselves.

According to Avicenna, for the baby's body development, the baby should be swung slowly but for the spiritual development, it is of great importance and necessity to the baby to listen to the mother's lullaby (Koçar 1991: 136).

According to Kristeva, it is the pre-oedipal stage or semiotics, called as the impulsive energy of the child, the period known as the "Babbling" in which the baby imitates the sounds, gestures and body movements. The rhythm and pronunciation of semiotics instinctive energy prepare the children for speech. (Sellers, 1991: 98)

After the baby is born, the first contacts are realized with and through mother. This form of interaction between mother and baby is the first tangible indication of the mother tongue and development. This interaction is also the basis for developing listening skills in children. The first step of this process will happen as listening, taking and transmitting successively and starts with the lullaby the mother sings with tunes.

In this context, lullabies are a kind of tools that have a cultural function and a directly or indirectly answer "to the derived needs". In this way, the continuity of social and cultural life is provided. The most influential person in the continuity of the tradition and culture is the mother who performs the lullabies. The mother establishes a one-to-one and deep relationship with the child through the lullabies she performs and starts to develop him about the desired behaviors in all areas of life.

\section{When the LULLABY is considered;}

Traditionally,

When lullaby is called, what first comes to everyone's' mind is the oral song that a mother sings to her baby or when we think of lullaby as a Picture, the first frame that appears in front of our eyes is a mother and a baby in her arms, and what we feel is the serenity, relaxation and calmness.

In Divanü lugati't-Türk (an old Turkish-Arabic dictionary for Turkic languages- by Mahmud ibn Hussayn ibn Muhammad al-Kashgari known shortly as Al-Kashgari), an interpretation called as "balubalu" was used for lullaby and it was explained that "a lullaby is used by women to put the baby to sleep in the cradle". 
Kaya, S. Ö., \& Özkut, B. (2016). The influence of developing technology and mother's songs; lullabies. International Journal of Human Sciences, 13(1), 778-786. doi:10.14687/ijhs.v13i1.3586

Lullaby is melody that is sung in mother's arms, at mother's knees or in the cradle by the mother to calm the crying baby to calm down or because it is time for the baby to sleep (Alptekin, 1990: 63).

Lullaby in the children's literature is defined as the poems that are sung with tunes by mothers to their milk era children (Şimsek, 2002: 35).

Lullaby is the first contact between mother and child. The mother addresses the child with lullabies, communicates and interacts with the child. Singing lullabies to the child every evening and doing it repeatedly are an indication of the order and stability of the family. Lullabies in time establish a common culture between mother and child. Lullaby is the fundamental expression of mutual empathy between mother and child.

Lullabies for children mark the sounds of preparation to sleep. These sounds reduce stress and regulate breathing. This is the sound of his mother's voice that the child knows best. This is a very warm and charming voice. This sound is a magic formula for preventing child's fears. This sound does not allow the dark buzzing or a fear to seize the child. In most of the lullabies, there are reassuring words for the child. These sounds and words look like the "security blanket" for the child. The blanket is a tool to protect the children from the outside world. When a child is scared, he mostly lays the blanket over him and then feels safe. The case is the same with the lullabies. It gives confidence to children, prevents fear and anxiety, and protects them against the outside world. (Leydier, quoted by Güneş from Durand, 2010, p.29).

In creating the lullabies, the feeling of motherhood dominates. The mother deals with the mother with the feelings since she possesses them from her own creation and sings her baby lullabies with all these feelings. Additionally, the women constitute the main pillar community so lullabies are used by them for the expression of their moral, philosophical and aesthetic understanding and the depth and richness of their feelings and thoughts. The lullabies are the product of women's intellect and their capability for creativity (Yildız 2003: 300). So lullabies are the long life lasting cultural and artistic education given to the child by the mother.

Lullabies are sung to the infants who are between at least two-three months old and three to four years old especially when mothers keep them on their lap, feet or shaking a cradle to put them to sleep quicker and easier and to silence the cry of the babies. Lullabies are a kind of ballads (Turkish poem) formed from a quadrature that reflects the general mood of the mother and are sung with a particular composition (Çelebioğlu, 1995: 9).

Lullabies are a special form of communication between mother and child, but also they are the material and spiritual food in the process of child's development. In addition, lullabies affect the whole family. The lullaby chants of the mother do not leave a mark not only on the baby who is being put to sleep but also in the ears, mind and heart of other children at home with the harmony it resonates (Çelebioğlu, 1987: 83).

Lullaby is the first contact between mother and child. The mother addresses the child with lullabies, communicates and interacts with the child. Singing lullabies to the child every evening and it is done repeatedly child are an indication of the order and stability of the family. Lullabies in time establish a common culture between mother and child. The poetic and soulful lyrics bring together children's learning a large number of words and phrases. Lullabies provide the child with a chance to meet oral tradition. Through humming, mother expresses her expectations, joys and hopes, sorrows, her concerns in a lullaby. Reassuring messages are supplied to the child by the mother. Research shows that children often prefer fun lullabies. In short, lullabies help the mothers to communicate with their children.

Lullabies are poems sung with tunes by mothers to their milk era children in verse or prose. They are the anonymous poem-songs. They are lyrical literature products of our cultural world. Lullabies are sung on mother's lap when they are swinging or kept in a rocking cradle after the children are 
Kaya, S. Ö., \& Özkut, B. (2016). The influence of developing technology and mother's songs; lullabies. International Journal of Human Sciences, 13(1), 778-786. doi:10.14687/ijhs.v13i1.3586

breastfed (Dönmez, and et al, 2000: 22). As a mother wants to calm the baby down and puts the baby to sleep in the crib or on her lap, she will start waving the baby with her rhythmic movements. She will also sing a lullaby with a special tune according to this rhythm. In this way, the children who grow up by listening to lullabies will improve the ability of "keeping pace" and "creating harmony" along with developing their native language (Kıraç, 1997: 38).

According to many researches today, babies are born by recognizing the sound of their mother. It was found out that after the birth of the baby, the baby would like to listen to the voice of their mother rather than the other women's (Güneş, 2007). In this context, the babies accompany the lullaby and song rhythms, repeat them in their own language universe and create their own unique music repertoire. This repertoire is a source for the children's speech and language learning in the future.

Almost the first articulation of language is started through the lullabies, which includes mother's love. This is important since it marks the first step of their language education. The lullabies make a huge contribution to the understanding of the melodic structure of the native language. Starting from the talking phase in ages between 0-5 (preschool), a pleasure and language development in children occurs. Since the children's first perception is introduced by ear, "mother's song" known also as lullabies gain further meaning in this scope (Dönmez et al, 2000: 22). Especially in this period, the lullabies that the baby hears generally from his mother introduce the baby with his mother tongue and they are the first tunes that stick in the baby's mind. The tunes sung lovingly are the most important tools and materials in the acquisition of this language. The baby, who carefully listens to her mother, monitors her over the time and starts mocking his native language, and then converts the acquired language into the mother tongue consciousness thanks to the audio and visual support.

Lullabies are filled with the symbolic messages established not only with the children but also with the mothers, and it can be said that with these aspects of lullabies, mothers have the chance of voicing their vital experience (Karabaş, 1999). Lullabies serve as a very special "communication tool" between mother and baby. Also, they are sometimes for the mothers rather than the child. The reason is that, although the baby does not understand at all, mothers communicate with the baby through lullabies, share their joy and pain with the baby. In other words, a spirit of serenity is supplied to the baby with the lullaby tunes and to the mother with the words and also functions as an important "psychotherapy" application (http://www.diledebiyat.net).

Today the claim that a child growing with the lullaby culture compared to a child that has been deprived of attention will have a more artistic character has been accepted by most of the scientists.

Lullabies are a type that cannot be considered separately from the women or mothers, the artistic creators. As the anonymous folk poem is considered, it is perhaps possible to say that there is no another kind integrated with its creator in this criterion. At first glance, lullabies are seen as short, simple and easy kind of songs to be sung. However, they strengthen the communication and compliance between mother and baby, calm the baby down, and reflect the thoughts and feelings of the mothers that cannot be expressed in daily life. Finally, they are the meaningful products including first messages about the desired set of values a child needs to gain. Thus, this kind should be evaluated in the context of the framework in between mother, baby and the environment since lullabies have positive impact on the child's development and demonstrate the mother's internal world.

\section{As We Examine the Studies Done On Lullabies}

The study named as "Analyzing the contributions of the lullabies to the development of the infants' domains via content analysis: Konya sample" by Kabaday1 (2009) and Bunte and Pavlicevic (2001) emphasized that there is a rhythmic coding between the mother and the new born, which comes 
Kaya, S. Ö., \& Özkut, B. (2016). The influence of developing technology and mother's songs; lullabies. International Journal of Human Sciences, 13(1), 778-786. doi:10.14687/ijhs.v13i1.3586

out in the baby's mental development; and add that this presence forms the heart of the first communication and interaction between them. When the issue is viewed from the baby's side, it has been observed that compared to other rhythmic parts, the baby listens to the lullabies performed by the mother with a much greater precision. In addition, it has been claimed that the lullabies performed by the family play a vital function in helping to strengthen the emotional bond between the baby and the family (Trehub, 2001).

The other study that has been published separately about lullabies belongs to Mebmet Senkaya and M. Saadettin Aygen (1980.) In the introduction part of the study that contained the lullabies sung in Afyon, some information that was in their previous works was introduced and then moved to the lullaby sung text. The work is partially pictured with figures of mothers, their babies and cradle.

Üçer (1976) has given Sivas lullabies in his article under the heading of birth folklore and pointed to lullabies being played to the baby via the radio and it was noted that the baby needs mother's smell, breathe and compassion.

Singing lullaby is a cycle that integrates love of the mothers with their children. Mothers put a lot of effort to practice the lullaby with the love they have for the babies. The babies who do not even know what love is yet but are born into this world armed with this feeling feel the love in his mother's voice and react to it, which exactly coincides with the case the mother want it to happen. In fact, what is most in need of the man cub is feeding its confidence feeling. According to Alfred Adler, child recognizes himself as inadequate and weak, needing to be protected and wants to be taken an important asset. Children have the feeling of fear of life and loneliness. They cannot live alone and desire to be cared for by a strong asset (Emre 2005: 74). Therefore, the lullabies whose only purpose is not relieving the children are the charming clue words which are the yeast of love and confidence for the child in the coming years and have the potential to bring together child with happiness (Göçer, 1999: 27).

Bunte and Pavlicevic (2001) emphasize that there is a rhythmic coding between the mother and the new born that comes out in the baby's mental development; and add that this presence forms the heart of the first communication and interaction between them. When the issue is viewed from the baby's side, it has been observed that compared to other rhythmic parts, the baby listens to the lullabies performed by the mother with a much greater precision. Also, it has been argued that the lullabies performed by the family play a vital function in helping to strengthen the emotional bond between the baby and the family (Trehub, 2001).

"Lullabies are known as an indicator of the child's and parents' personal process. If no lullaby is sung in a house, this is a sign that there is a problem among parents, child and their environment. Today, in addition to the development of technology and parents' hard work, the chance of singing the lullabies to the children in person has reduced. Today, if a parent doesn't sing a lullaby to his child, then they are likely to prefer to use mechanical music boxes to record the lullabies rather than choosing to lie down closer to his children and singing a lullaby to his child (Weiser, 2000: 244).

Today, mothers put their babies to sleep by inserting a cassette into a tape machine or putting CD into a CD player. This change is the only one aspect of lullaby traditions. Some of the mass media tools have just begun to take a bigger place in our life. It is not difficult to predict how effective the most frequently used means of communications such as television, mobile phone and the internet in today's modern technology will stand for the future mother-child relationship in the next generation.

Technology culture doubtlessly offers great services in reaching the knowledge easily, following the immediate innovations or developments along with educating and training the community, but it should be remembered it would be more useful when they are used at the right time in the right place and used for the right purposes. Otherwise, this culture would harm the humanity more than 
Kaya, S. Ö., \& Özkut, B. (2016). The influence of developing technology and mother's songs; lullabies. International Journal of Human Sciences, 13(1), 778-786. doi:10.14687/ijhs.v13i1.3586

the benefits it may supply. Besides, we will face with the danger of leaving the national culture and losing the traditional values along with technology culture that is devoid of historical roots. Our task is not to reject technology, adversely to take advantage of it in a positive sense and also to raise awareness among our people in that direction; to raise individuals to be open to innovation but connected to our traditional culture. Socio-cultural changes in life based on the technological developments have negatively affected the mother, the lullaby performer, and the tradition of singing lullaby. Parallel to these, the lullabies have undergone some changes of the overall structure in terms of content and form.

The lullabies hold a very deep and an old place in our own culture and are the precious treasure chest of our culture. It is vital that the natural fit of lullabies be preserved by not allowing the mothers forget the picture of mother-baby-crib so that the lullabies could be transferred to the next generations in a quality and a natural form. By the help of lullabies, mothers find a way to express their thoughts and feelings to their babies. Most mothers and babies look at each other just as the mothers sing the lullabies to their babies. This is an important and effective way for the mothers to strengthen the bond with their babies. The strong, positive and secure bond established between mother and child is the first step of the sharing the interest, love, support, compassion and full of entertainment that is to last lifetime for both sides.

One of the main reasons why we identified the subject of the study as the lullabies is that there are rich and an important number of lullabies in our culture. Another main reason is the danger that some of our customs and traditions may melt away with the rapidly evolving technology. However, our lullabies are magical mothers' songs and a part of cultural heritage of our country that should be transferred from one generation to the other.

The current study implies that the naturalness of our lullabies should be preserved as the lullabies are regarded as the precious treasure chest of our own culture and they hold a very deep and an old place. The study aims to bridge the gap by providing the idea that lullabies should be transferred to the upcoming generation in a quality, traditional and natural fit. Additionally, to do so, motherbaby-crib figure should not be allowed to be forgotten by the mothers. It was put forward that by this study that mothers should repeat the lullabies so that transfer of the lullabies from one generation to the other could be carried out.

It should be noted that the history of the lullaby which is a magical bond between mother and child dates back to the Sumerians and has 4000 years of history.

\section{CONCLUSIONS AND SUGGESTIONS}

It is not difficult to predict how effective the most frequently used means of communications such as television, mobile phone and the internet in today's modern technology will be for the future mother-child relationship in the next generation. However, as we think of lullabies, we create a picture in our minds, our souls and our imagination a figure of a mother, a baby and a cradle. Trying to put the baby to sleep with the lullaby CDs or with the lullabies played directly from the internet sites partially eliminate the communication functions of the lullabies.

Socio-cultural changes occurring in life depending on the technological developments have negatively affected a lullaby performer, the mother, and the tradition of lullaby singing. Accordingly, the lullabies have undergone some changes in the overall structure in terms of content and form.

The past studies show that the lullabies can be used for lifelong education and as a result of that lullabies contribute to the children's language, emotional, social and physical development as well as their mental development at an early age. In the light of the information collected through the literature review, it has been reached that lullabies have an important place in the education of 
Kaya, S. Ö., \& Özkut, B. (2016). The influence of developing technology and mother's songs; lullabies. International Journal of Human Sciences, 13(1), 778-786. doi:10.14687/ijhs.v13i1.3586

children since they transport the cultural elements. According to research results, lullabies are a part of the culture and it was concluded that lack of lullabies is a major shortcoming in terms of culture.

It is seen that lullabies pose some functions such as strengthening communication and harmony between mother and baby, relaxing and calming down the baby as well as instilling certain fundamental values of our society to the baby.

Lullabies are a kind of art that cannot be considered separately from the artistic creators; that is the mothers. When the anonymous folk culture is considered, it is perhaps possible to say that there is no another kind integrated with its creator in this criterion.

It was seen that improving technology has affected the lullabies. Although just like it used to be in the past when a lullaby was considered to be case of a mother, today with the technology the mother's responsibility in society has increased so that music players, PCs have replaced women in relation with the lullabies. Thus, in this electronic culture media, performing lullabies has taken a very different character. On the one hand, mothers have become active users revealed by the electronic culture media tools but on the second hand they have started to become passive in the performing the lullabies thanks to the speed and the easiness of these tools.

In this context, technology culture will do more harm than to benefit humanity. We will be faced with the danger of leaving the national culture and losing the traditional values along with replacement of a technology culture devoid of historical roots. Our task is not to reject technology, adversely to take advantage of it in a positive sense and also to raise awareness among our people in that direction; to raise individuals open to innovation but connected to our traditional culture.

When lullaby texts are examined, it is understood that perhaps lullabies have a more important task than just putting the baby to sleep. It is definitely related to children's education. We can say that one of the points that are overlooked by folklore experts and pedagogues is the educational aspect of the lullabies.

It was considered that lullabies are the most important communication tool with outside world for infants. It was found out that the infants get relaxed even they are in the mother's womb as the mothers start singing lullabies. Moreover, after a certain time the infants were found to have shown reaction to this voice coming.

It is a necessity that the lullabies should be preserved and even more mothers' awareness of the lullabies should be raised by educational institutions and through both mass media along with informing the importance of singing lullabies to children should be emphasized in this regard. In the training centers that are founded in several cities mother should be given training about lullabies and performing lullabies. In addition, within the scope of lifelong music and art education, seminars and workshops relating to lullabies could be organized for mothers and educators by conservatories or department of music education in the faculty of education.

Language acquisition of the children starts from the first month of birth. To raise awareness among the future mothers to give birth to today's babies on the importance of the lullabies on their infants' development; courses may be opened by universities and Ministry of Education or the municipalities. Under the leadership of the universities, mothers' attendance to educational activities could be provided by an organization among the institutions so they could realize the important role of singing lullabies in child's development. Mothers may be taught how they will perform lullabies.

A lullaby archive which is an important part of folk culture archives can be edited about our lullabies. Mothers may be provided with some options to benefit from this archive.

The importance of our lullabies was mentioned in our study as they are regarded as the precious treasure chest of our own culture and they hold a very deep and an old place. It was also advised 
Kaya, S. Ö., \& Özkut, B. (2016). The influence of developing technology and mother's songs; lullabies. International Journal of Human Sciences, 13(1), 778-786. doi:10.14687/ijhs.v13i1.3586

that the naturalness of our lullabies should be preserved as a result of that they could be transferred to the upcoming generation in a quality and a natural fit. Besides, it was suggested that much things should be done so as not to let the mothers forget the picture of mother-baby-crib. The idea was highlighted by this study that it is necessary to repeat the lullabies by the mothers, the major performers, so that transmission of the lullabies from one generation to the other generation could be carried out.

\section{Bibliography}

Alptekin, A.B. (1990), "Ninni”,'Türk Dili ve Edebiyatı Ansiklopedisi,C.VII, İstanbul:Dergâh Yayinlar1, s.63- 65.

Ayverdi, İ. (2006).Misalli Büyük Türkşe Sö̊lük, 2. Bask1, Kubbealtı Neşriyat, İstanbul.

Çelebioğlu, A. (1987).Ninnilerimiz̨e Dair, Çocuk Edebiyatı Yıllı̆ğ, Gökyüzü Yayınları İstanbul.

Çelebioğlu, A.(1995), Türk Ninniler Hazinesi, İstanbul: Kitabevi Yayınları.

Çı̆̆ M. İ. (2002). Ortadoğu Uygarlık Mirası. İstanbul :Kaynak Yayınları.

Çobanoğlu Ö. (2000). Geleneksel Dünya Görüşü veya Halk Felsefesinin Halkbilimi Çalışmalarındaki Yeri ve Önemi Üzerine Tespitler. Millî Folklor, yll 12, say1 45, 2000, 12-14.s.

Demir, N. (2008). “Türk Ninnilerinin Dili.” Ankara: Akçă̆ Yayınevi.

Dönmez, N. B., Abidoğlu, Ü., Dinçer, Ç., Erdemir, N., Gümüşçü, Ş. (2000) Okul Öncesi Dönemde Dil Gelisimi Etkinlikleri, Ya-Pa Yayınlan, İstanbul

Emre İ.(2005). Edebiyat ve Psikoloji. Ankara: Anı Yayınc1lı.

Göçer A. (1999). Çocuk ve Ninni. Erciyes, 22 (260) Ağustos 1999.

Güneş, F. (2007 ). Ses Temelli Cümle Yöntemi ve Zibinsel Yapılandırma, Nobel Yay.

Güneş, F. (2010). Ninnilerin çocukların dil ve zihinsel gelişimine etkisi. Zeitschrift für die Welt der Türken, 2(3),27-38.

Kabadayı, A. (2009).” Ninnilerin çocuğun gelişim alanlarına katkılarının içerik açıdan incelenmesi: Konya örneği. Uluslararası İnsan Bilimleri Dergisi ,Cilt:6,Sayı:1

Karabaş, S. (1999) Bütüncül Türk Budunbilimine Doğru, Yap1 Kredi Yayınları, İstanbul.

Kıraç, E. (1997). “Türk Halk Şiirinde Ritm, Ezgi ve Ninni Söyleme Geleneğinin Rolü”. PAÜ Eğitim Fakë̈ltesi Dergisi 3: 38-44.

Koçar Ç. (1991). Türkistan ile İlgili Makaleler. Ankara: Kültür Bakanlı̆̆1 Yayınları.

Ong W. (1995). Sö₹lü ve Yaz̨l Kültür. İstanbul: Metis Yayınları.

Şenkaya M. (1980). Aygen, M. Saadettin. Afyon'da Söylenen Ninniler. Afyon: Türkeli Yayınları.

Şimşek, T. (2002), Çocuk Edebiyatı, İstanbul, Suna Yayınları.

Tezcan, M. (2000). Türk Ailesi Antropolojisi, Ankara, İmge Kitapevi Yayınları .

Üçer M. (1976). Sivas’ta Doğum Folkloru. Sivas Folkloru, 4,47 (1976) 8-12.s

Yıldız N.(2003). Ninniler. Türk Dünyası Edebiyatı Taribi. Ankara: Atatürk Kültür Merkezi Yayınları.

Weisner S. (2000). The mythology of infancy: lullabies from a Jungian perspective, Pacifica Graduate Institute, Degree of Doctor of Philosophy in Clinical Psychology

http://www.diledebiyat.net/turk-edebiyati-tarihi 